\title{
Effect of Farming Systems on the Spatial Variability of Soil Physical Properties and Soybean Yield
}

\author{
Ligia Maria Lucas Videira ${ }^{1}$, Paulo Ricardo Teodoro Silva ${ }^{1}$, Diego dos Santos Pereira ${ }^{1}$, Rafael Montanari ${ }^{1}$, \\ Alan Rodrigo Panosso ${ }^{2} \&$ Christtiane Fernandes Oliveira ${ }^{3}$ \\ ${ }^{1}$ Department of Plant Health, Rural Engineering, and Soils, College of Engineering, São Paulo State University, \\ Ilha Solteira, SP, Brazil \\ ${ }^{2}$ Department of Exact Sciences, São Paulo State University, Jaboticabal, SP, Brazil \\ ${ }^{3}$ School of Agricultural Engineering, University of Campinas, Campinas, SP, Brazil \\ Correspondence: Diego dos Santos Pereira, Department of Plant Health, Rural Engineering, and Soils, College \\ of Engineering, São Paulo State University, Ilha Solteira, SP, Brazil. Tel: 55-189-8119-9561. E-mail: \\ diegol_360@hotmail.com
}

Received: June 17, 2019

Accepted: July 24, 2019 Online Published: September 15, 2019

doi:10.5539/jas.v11n15p87

URL: https://doi.org/10.5539/jas.v11n15p87

\begin{abstract}
In no-tillage (NT) and minimum tillage (MT) areas, spatial variability of soil physical properties may affect crop yield. The aim of this study was to assess the spatial distribution of soil physical properties, as well as the yield components and grain yield of soybean (GY), based on the mapping of areas under soil conservation farming systems. We assessed yield components, GY and the physical properties of an Oxisol, under NT and MT using the t-student test, and geostatistics to assess spatial variability. The largest population of NT plants showed no spatial dependence and did not influence GY, but the components related to plant height and soil properties differed between systems. From a spatial standpoint, the kriging maps demonstrated that mass of one thousand grains (MOG), total porosity (TP) and soil bulk density (BD) influenced GY under NT, whereas TP1 exerted the most influence under high soil moisture conditions and MT. The maps make it possible to assess the spatial distribution of soil physical properties and the influence on GY, making them an important tool for more accurate production planning in soil conservation systems.
\end{abstract}

Keywords: Glycine max L., minimum tillage, no-tillage, soil physical properties

\section{Introduction}

The Brazil advances to become the largest producer of soybeans in the world, this should happen with greater investment in production technology (Pereira et al., 2018a). This is partly due to the use of conservation farming systems, such as NT (no-tillage) and MT (minimum tillage), which promote improved soil quality, enabling cropping systems to cover vast areas (Cortez et al., 2017).

Soil conservation systems, which leave crop residue on the soil surface, include MT (using scarifiers) and NT (Dam et al., 2005). NT is based on the application of a set of technologies to avoid soil disturbance, the permanent maintenance of soil surface with crop residue and crop rotation (Moraes et al., 2017). Its worldwide use is increasing because it results in faster and more efficient operations, in addition to improving soil physical conditions for better crop development and growth (Tavares Filho et al., 2012; Pereira et al., 2018a). According to Kassam et al. (2018), NT encompassed 180 million hectares in 2015/16, 32 million of which were in Brazil, making the country's agriculture one of the most sustainable in the world (Freitas \& Landers, 2014).

However, compacted and subcompacted layers emerge as a result of fewer soil operations (Franchini et al., 2011), making it a limiting factor in achieving maximum crop yield (Araújo et al., 2004). With the higher BD, penetration resistance (PR) and microporosity (MI) increase, causing a decline in TP, macroporosity (MA) and hydraulic conductivity (Rosa Filho et al., 2009). Scarification has been adopted to reverse this process, based on the principles of NT (Bertolini \& Gamero, 2010; Nunes et al., 2014).

The effects of soil turning vary, with crops responding differently in terms of grain yield (Moraes et al. 2017; Pereira et al., 2018a). To better understand and analyze the spatial behavior of soil and plant properties, geostatistics is used to detect the variability and spatial distribution of the properties, by constructing maps 
considering the position of the sample, generated according to interpolated data (Aubert et al., 2012; Alves et al., 2014; Betzek et al., 2017; Cortez et al., 2018). Their use is important in selecting production processes to increase agricultural profits with minimal environmental impact by adapting soil management to variable field conditions (Bottega et al., 2017). In this respect, our aim was to assess the spatial distribution of yield components, GY and soil physical properties by mapping of soybean crop areas, under NT and MT.

\section{Method}

\subsection{Experimental Area}

The study was conducted in 2015/2016 in an experimental area belonging to São Paulo State University (UNESP), at the School of Natural Sciences and Engineering of Ilha Solteira, São Paulo state, located in the city of Selvíria-MS (Brazil), at coordinates $20^{\circ} 20^{\prime} \mathrm{S}$ and $51^{\circ} 24^{\prime} \mathrm{W}$, and average altitude of $344 \mathrm{~m}$. The climate in the region is Aw, according to Köppen's classification, characterized as tropical wet-dry, with a rainy season in the summer and dry season in the winter, average annual rainfall of $1,300 \mathrm{~mm}$ and temperature of $23.7^{\circ} \mathrm{C}$. Figure 1 presents the monthly temperature, humidity and rainfall during the experiment.

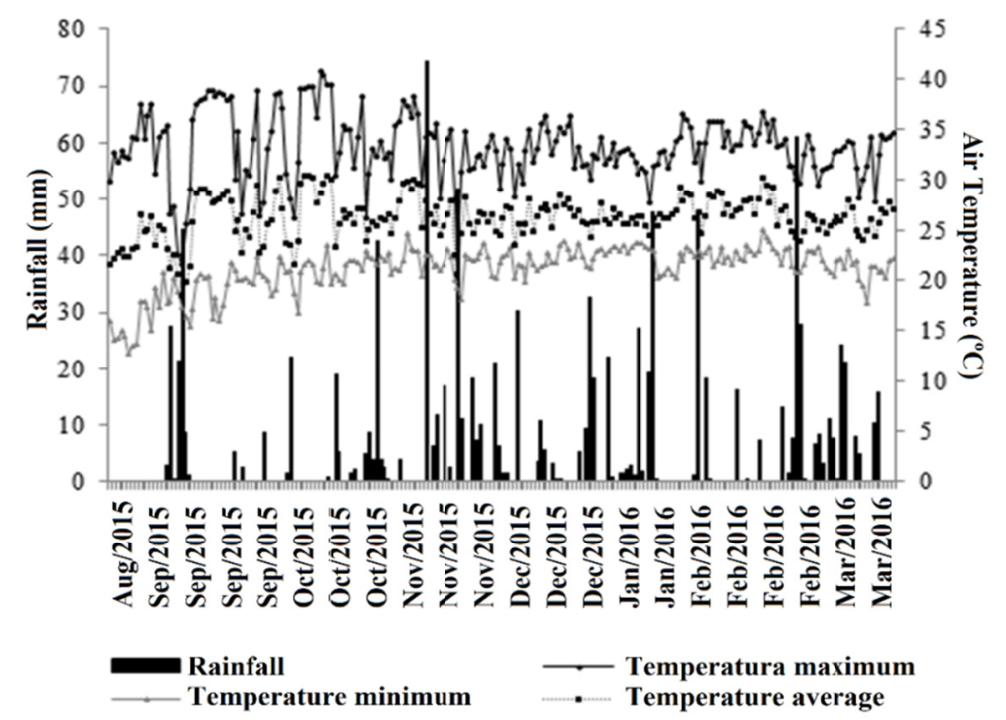

Figure 1. Rainfall (mm), minimum, maximum and mean temperature $\left({ }^{\circ} \mathrm{C}\right)$ during the $2015 / 2016$ growing season

The soil in the area is classified as Latossolo Vermelho distrófico, Brazilian classification (Santos et al., 2013), corresponding clayey dystrophic Oxisol with granulometry averaging $440 \mathrm{~g} \mathrm{~kg}^{-1}, 165 \mathrm{~g} \mathrm{~kg}^{-1}$ and $395 \mathrm{~g} \mathrm{~kg}^{-1}$ for clay, silt and sand, respectively. Before the experiment, the soil exhibited the following chemical characteristics: phosphorous $\left(\mathrm{P}_{\text {resin }}\right): 31 \mathrm{mg} \mathrm{dm}^{-3}$ and $20 \mathrm{mg} \mathrm{dm}^{-3}$; organic matter $(\mathrm{OM}): 27 \mathrm{~g} \mathrm{dm}^{-3}$ and $19 \mathrm{~g} \mathrm{dm}^{-3}, \mathrm{pH}\left(\mathrm{CaCl}_{2}\right): 5.1$ and 4.7, potassium (K): $5 \mathrm{mmol}_{\mathrm{c}} \mathrm{dm}^{-3}$ and $2.4 \mathrm{mmol}_{\mathrm{c}} \mathrm{dm}^{-3}$, calcium $(\mathrm{Ca}): 27 \mathrm{mmol}_{\mathrm{c}} \mathrm{dm}^{-3}$ and $10 \mathrm{mmol}_{\mathrm{c}} \mathrm{dm}^{-3}$, magnesium (Mg): $20 \mathrm{mmolc} \mathrm{dm}^{-3}$ and $10 \mathrm{mmol}_{\mathrm{c}} \mathrm{dm}^{-3}$, aluminum (Al): $0 \mathrm{mmolc} \mathrm{dm}^{-3}$ and $4 \mathrm{mmolc} \mathrm{dm}^{-3}, \mathrm{H}+\mathrm{Al}$ : $38 \mathrm{mmolc} \mathrm{dm}^{-3}$ and $42 \mathrm{mmolc} \mathrm{dm}^{-3}$, SB: $52.8 \mathrm{mmolc} \mathrm{dm}^{-3}$ and $28.4 \mathrm{mmolc} \mathrm{dm}^{-3}$, CTC: 90 mmolc dm${ }^{-3}$ and 70.4 mmolc dm$~^{-3}$, V: $58 \%$ and $40 \%$. Chemical analysis and fertilization were carried out according to Raij (2011) and Cantarella et al. (1997). Thus, with a view to increasing base saturation, $2.08 \mathrm{t} \mathrm{ha}^{-1}$ of lime were applied to the area, with $\mathrm{CaO}: 28.0 \%$ and $\mathrm{MgO}: 20.0 \%$.

\subsection{History of the Area}

Before conducting the experiment, the $6,400 \mathrm{~m}^{2}$ area, which undergoes center pivot irrigation, was used for annual crops until 1987. In 1998 and 2003, the soil was prepared using conventional tillage (plowing). In the other years, the crops were planted under NT until 2010. In 2011/2012, the area was used to plant corn for silage, together with Urochloa brizantha and Megathyrsus maximum. From 2012/2013 onward, corn in summer and bean in winter were the last successor crops in the area before the experiment. In September 2015, millet (Pennisetum glaucum L.), cultivar BRS 1501, was planted and dessicated with glyphosate 40 days after planting $\left[1,440 \mathrm{~g} \mathrm{ha}^{-1}\right.$ of the active ingredient (i.a.) $]$. 


\subsection{Experimental Design}

The area was divided in December 2015, and 3,200 $\mathrm{m}^{2}$ were allocated to MT and the rest to NT. The MT consisted of mechanical soil scarification, up to $0.37 \mathrm{~m}$, followed by leveling and crushing. Next a sample grid consisting of 51 sampling points was divided into three $160 \mathrm{~m}$ transections, in order to cover each $3,200 \mathrm{~m}^{2}$ area.

\subsection{Crop Planting}

Soybean was planted using the M 7110 IPRO cultivar, with indeterminate growth. Between-row spacing was $0.45 \mathrm{~m}$, with a density of 15.9 plants per meter in the row. In line with crop recommendations, $250 \mathrm{~kg} \mathrm{ha}^{-1} \mathrm{of}^{-1}$ 04-20-20 (N-P-K) formulation was applied. The fungicide carboxin $\left(50 \mathrm{~g} \mathrm{ha}^{-1}\right.$ do i.a. $)+$ thiram $\left(50 \mathrm{~g} \mathrm{ha}^{-1}\right.$ do i.a. $)$ was used to treat $100 \mathrm{~kg}$ of seed, followed by the liquid inoculant Bradyrhizobium sp. to supply 600,000 cells per seed.

\subsection{Analyses of Yield Components and Grain Yield of Soybean}

Soil collections, assessments and harvests occurred in March 2016, in the phenological stage R8 soybean. The final population of soybean plants (POP, plants $\mathrm{ha}^{-1}$ ) was counted along eight meters of the crop line around each sampling point. The plants were manually harvested for mechanical threshing GY $\left(\mathrm{kg} \mathrm{ha}^{-1}\right)$ was calculated, corrected to $13.0 \%$ (wet basis), and MOG was measured on a scale accurate to $\pm 0.01 \mathrm{~g}$, at $13.0 \%$ (wet basis). During harvesting, 10 plants were separated at each sampling point to determine the following: height of insertion of the first legume (HL, m), measuring the distance from the ground to the first legume, number of legumes per plant (LP), by counting the legumes in plants containing seeds and dividing by the number of plants sampled, plant height (HP, m), measuring the distance from the ground to the apex of the main stem, number of grains per plant (GP), by counting the seeds and dividing by the number of plants sampled, number of grains per legume (GL), by counting the number of seeds and dividing by the number of legumes in the sampled plants.

\subsection{Analyses of Soil Properties}

Sample were collected in layers $0.00-0.10 \mathrm{~m}$ and $0.10-0.20 \mathrm{~m}$ around each sampling point to determine soil physical properties. Undisturbed soil samples in volumetric cylinders were used to calculate MA $\left(\mathrm{m}^{3} \mathrm{~m}^{-3}\right)$, MI $\left(\mathrm{m}^{3} \mathrm{~m}^{-3}\right)$, TP $\left(\mathrm{m}^{3} \mathrm{~m}^{-3}\right)$, and BD $\left(\mathrm{kg} \mathrm{dm}^{-3}\right)$ values, applying the tension table method described by Teixeira et al. (2017). An impact penetrometer was used to determine PR (MPa), according to Stolf et al. (2014). Disturbed samples were collected to determine gravimetric moisture $\left(\mathrm{GM}, \mathrm{kg} \mathrm{kg}^{-1}\right)$ and volumetric moisture $\left(\mathrm{VM}, \mathrm{m}^{3} \mathrm{~m}^{-3}\right)$, in line with the methodology described by Donagema et al. (2011), and volumetric moisture using Hydrosense system $\left(\mathrm{Vh}, \mathrm{m}^{3} \mathrm{~m}^{-3}\right)$.

\subsection{Statistical Analysis}

The average values of yield components, soybean yield and soil physical properties were submitted to the Shapiro-Wilk test of normality, followed by analysis of variance applying the $F$ test $(p \leq 0.05)$. When a significant difference was observed, the average plant and soil properties were compared using the $t$-student test $(\leq 0.05)$ and $\mathrm{R}$ software (R Core Team, 2014).

\subsection{Geostatistical Analysis}

Statistical analysis was used to obtain the mean and frequency distribution, using SAS ${ }^{\circledR}$ software (SAS Institute, 2002). Spatial dependence was analyzed for each property by calculating a semivariogram, the nugget effect $\left(\mathrm{C}_{\mathrm{o}}\right)$, range $\left(A_{o}\right)$, sill $\left(C_{o}+C\right)$, coefficient of determination $\left(r^{2}\right)$ and residual sum of squares (RSS). Kriging maps were obtained by interpolation in order to analyze the spatial dependence between the properties, using Gamma Design version $7.0\left(\mathrm{GS}^{+}, 2004\right)$.

\section{Results and Discussion}

The effects of MT and NT influenced POP, HP and HL, with no effect on GY, MOG, LP, GP and GL (Table 1). POP was lower in MT, and soil turning with scarifier blades likely affected seed deposition and cover in the soil, exposing them to heat, thereby hindering plant emergence because planting occurred after scarification. This did not occur in NT, since planting maintains crop residue on the soil surface, providing favorable plant emergence conditions. Cortez et al. (2017) also found lower POP in scarified soil compared to NT. The authors attribute this behavior to less seed-soil contact when exposed to higher temperatures, which affected water absorption. 
Table 1. Effect of minimum and no-tillage on yield components and soybean yield (Mean $\pm \mathrm{SD})$

\begin{tabular}{llllll}
\hline Properties $^{\mathrm{a}}$ & & \multirow{2}{*}{ Minimum tillage } & No-tillage & \multicolumn{2}{c}{$\mathrm{Pr}^{2} \mathrm{w}^{\mathrm{b}}$} \\
\cline { 5 - 6 } & & & & Minimum tillage & No-tillage \\
\hline GY $\left(\mathrm{kg} \mathrm{ha}^{-1}\right)$ & NS & $4.25 \pm 507.29$ & $4.43 \pm 456.18$ & $0.112^{\mathrm{NO}}$ & $0.484^{\mathrm{NO}}$ \\
LOG $(\mathrm{g})$ & $\mathrm{NS}$ & $49.24 \pm 0.92$ & $16.19 \pm 0.84$ & $0.007^{\mathrm{IN}}$ & $0.020^{\mathrm{TN}}$ \\
GP & NS & $114.30 \pm 16.05$ & $112.00 \pm 19.83$ & $0.089^{\mathrm{NO}}$ & $0.042^{\mathrm{TN}}$ \\
GL & NS & $2.31 \pm 0.15$ & $2.28 \pm 0.16$ & $0.474^{\mathrm{NO}}$ & $0.736^{\mathrm{NO}}$ \\
HP $(\mathrm{m})$ & $* *$ & $1.00 \pm 0.05 \mathrm{a}$ & $0.95 \pm 0.07 \mathrm{~b}$ & $0.020^{\mathrm{TN}}$ & $0.496^{\mathrm{NO}}$ \\
HL $(\mathrm{m})$ & $*$ & $0.15 \pm 0.01 \mathrm{~b}$ & $0.16 \pm 0.01 \mathrm{a}$ & $0.437^{\mathrm{NO}}$ & $0.015^{\mathrm{TN}}$ \\
POP $\left(\mathrm{pl} \mathrm{ha}{ }^{-1}\right)$ & $* *$ & $253.15 \pm 18.19 \mathrm{~b}$ & $281.80 \pm 20.76 \mathrm{a}$ & $0.798^{\mathrm{NO}}$ & $0.347^{\mathrm{NO}}$ \\
\hline
\end{tabular}

Note. ${ }^{\mathrm{a}} \mathrm{GY}$, grain yield of soybean; MOG, mass of one thousand grains; LP, number of legumes per plant; GP, number of grains per plant; GL, number of grains per legume; HP, plant height; HL, height of insertion of the first legume; POP, final population of soybean plants. ${ }^{b}$ Frequency distribution: NO, normal; $\mathrm{TN}$, tending to normal; IN, indeterminate. Different lower-case letters in each column indicate differences between farming systems: NS not significant; $* \mathrm{P}<0.05 \%$ and ${ }^{* *} \mathrm{P}<0.01$ (with the t-student test).

Table 1 shows that HL under NT was higher than that of MT, and the greatest HP was obtained in MT. Soil scarification may have favored root distribution, allowing greater soil exploitation and increasing plant height. However, since water availability was the same between systems, the best plant development did not lead to a rise in GY. The HL and HP are important characteristics in crop development, since plants with HL lower than $0.15 \mathrm{~m}$ exhibit greater crop losses, while taller plants display a higher lodging incidence, which may limit the performance of harvesters.

Despite the similar GY between NT and MT (Table 1), yields were higher than those reported by Rosa Filho et al. (2009), who assessed NT in an Oxisol, and similar to those observed by Girardello et al. (2014), who also found no GY difference in Oxisol under NT and a scarified area. The use of scarifiers in planting systems does not always increase soybean yield (Cortez et al., 2017). Soybean is considered a rustic crop, with a limited response to soil interventions under favorable climate conditions (Pivetta et al., 2011). The results confirm that changes in crop yield may not be only a function of soil, which means that the best physical soil condition may not necessarily result in higher yields (Nunes et al., 2014).

Mechanical soil scarification prompted a reduction BD and an increase in GM, VM, MA, MI, TP and PR, in both layers (Tables 2 and 3). BD increased in NT, with a change in TP, a predominance of MI and decline in MA, caused by less soil turning. With no soil turning, the pressures caused by farm machinery traffic and the natural settlement of particles raise soil compaction, thereby reducing pore size (Godoy et al., 2015). Pereira et al. (2018b) assessed native forest in the Cerrado and in found BD values in natural Oxisol close to those recorded under MT, indicating compaction in the NT area and the effects of decompaction in MT. Additionally, higher GM and VM values may be related to the increase in MI under MT, retaining more water in the soil, despite the NT exhibiting more plant residue on the soil surface. The MA values in NT were lower than $0.10 \mathrm{~m}^{3} \mathrm{~m}^{-3}$ (Tables 2 and 3), which is considered the limit for the development of most species (Collares et al., 2008). However, they did not restrict crop development, given that yield was similar between systems. These results are corroborated by Silveira et al. (2008), who found that NT obtains higher BD values, and lower MA and TP values, due to the absence of soil turning. Mazurana et al. (2011) observed that scarification reduced BD and PR, in addition to increasing water infiltration. 
Table 2. Effect of minimum and no-tillage on soil physical properties, in the 0.00 to $0.10 \mathrm{~m}$ layer $(\mathrm{Mean} \pm \mathrm{SD})$

\begin{tabular}{|c|c|c|c|c|c|}
\hline \multirow{2}{*}{ Properties $^{\mathrm{a}}$} & & \multirow{2}{*}{ Minimum tillage } & \multirow{2}{*}{ No-tillage } & \multicolumn{2}{|c|}{$\operatorname{Pr}<W^{b}$} \\
\hline & & & & Minimum tillage & No-tillage \\
\hline MA1 $\left(\mathrm{m}^{3} \mathrm{~m}^{-3}\right)$ & $* *$ & $0.126 \pm 0.04 \mathrm{a}$ & $0.054 \pm 0.02 \mathrm{~b}$ & $0.941^{\mathrm{NO}}$ & $0.008^{\mathrm{IN}}$ \\
\hline $\operatorname{MI} 1\left(\mathrm{~m}^{3} \mathrm{~m}^{-3}\right)$ & $*$ & $0.369 \pm 0.03 \mathrm{a}$ & $0.354 \pm 0.02 \mathrm{~b}$ & $0.644^{\mathrm{NO}}$ & $0.513^{\mathrm{NO}}$ \\
\hline $\mathrm{TP} 1\left(\mathrm{~m}^{3} \mathrm{~m}^{-3}\right)$ & $* *$ & $0.496 \pm 0.04 \mathrm{a}$ & $0.408 \pm 0.03 \mathrm{~b}$ & $0.801^{\mathrm{NO}}$ & $0.397^{\mathrm{NO}}$ \\
\hline $\mathrm{BD} 1\left(\mathrm{~kg} \mathrm{dm}^{-3}\right)$ & $* *$ & $1.317 \pm 0.11 \mathrm{~b}$ & $1.542 \pm 0.09 \mathrm{a}$ & $0.917^{\mathrm{NO}}$ & $0.056^{\mathrm{NO}}$ \\
\hline GM1 $\left(\mathrm{kg} \mathrm{kg}^{-1}\right)$ & $* *$ & $0.264 \pm 0,02 \mathrm{a}$ & $0.218 \pm 0.02 \mathrm{~b}$ & $0.268^{\mathrm{NO}}$ & $0.683^{\mathrm{NO}}$ \\
\hline $\operatorname{VM} 1\left(\mathrm{~m}^{3} \mathrm{~m}^{-3}\right)$ & $* *$ & $0.347 \pm 0.04 \mathrm{a}$ & $0.336 \pm 0.03 \mathrm{~b}$ & $0.410^{\mathrm{NO}}$ & $0.148^{\mathrm{NO}}$ \\
\hline $\operatorname{Vh} 1\left(\mathrm{~m}^{3} \mathrm{~m}^{-3}\right)$ & $*$ & $0.285 \pm 0.05 \mathrm{~b}$ & $0.310 \pm 0.04 \mathrm{a}$ & $0.503^{\mathrm{NO}}$ & $0.000^{\mathrm{IN}}$ \\
\hline PR1 (MPa) & $* *$ & $0.381 \pm 0.20 \mathrm{~b}$ & $0.588 \pm 0.25 \mathrm{a}$ & $0.155^{\mathrm{NO}}$ & $0.050^{\mathrm{NO}}$ \\
\hline
\end{tabular}

Note. ${ }^{\mathrm{a}} \mathrm{MA}$, macroporosity; MI, microporosity; TP, total porosity; BD, bulk density; GM, gravimetric moisture; VM, volumetric moisture; Vh, volumetric moisture using Hydrosense system; PR, penetration resistance. $\mathrm{b}$ Frequency distribution: NO, normal; TN, tending to normal; IN, indeterminate. Different lower-case letters in each column indicate differences between farming systems: NS not significant; ${ }^{*} \mathrm{P}<0.05 \%$ and ${ }^{* *} \mathrm{P}<0.01$ (with the t-student test).

Table 3. Effect of minimum and no-tillage on soil physical properties, in the 0.10 to $0.20 \mathrm{~m}$ layer (Mean $\pm \mathrm{SD}$ )

\begin{tabular}{|c|c|c|c|c|c|}
\hline \multirow{2}{*}{ Properties $^{\mathrm{a}}$} & & \multirow{2}{*}{ Minimum tillage } & \multirow{2}{*}{ No-tillage } & \multicolumn{2}{|c|}{$\operatorname{Pr}<w^{b}$} \\
\hline & & & & Minimum tillage & No-tillage \\
\hline $\operatorname{MA} 2\left(\mathrm{~m}^{3} \mathrm{~m}^{-3}\right)$ & $* *$ & $0.096 \pm 0.03 \mathrm{a}$ & $0.054 \pm 0.01 \mathrm{~b}$ & $0.564^{\mathrm{NO}}$ & $0.345^{\mathrm{NO}}$ \\
\hline $\operatorname{MI} 2\left(\mathrm{~m}^{3} \mathrm{~m}^{-3}\right)$ & $* *$ & $0.377 \pm 0.02 \mathrm{a}$ & $0.346 \pm 0.02 \mathrm{~b}$ & $0.413^{\mathrm{NO}}$ & $0.897^{\mathrm{NO}}$ \\
\hline $\mathrm{TP} 2\left(\mathrm{~m}^{3} \mathrm{~m}^{-3}\right)$ & $* *$ & $0.474 \pm 0.02 \mathrm{a}$ & $0.401 \pm 0.02 \mathrm{~b}$ & $0.991^{\mathrm{NO}}$ & $0.055^{\mathrm{NO}}$ \\
\hline BD2 $\left(\mathrm{kg} \mathrm{dm}^{-3}\right)$ & $* *$ & $1.378 \pm 0.09 \mathrm{~b}$ & $1.554 \pm 0.05 \mathrm{a}$ & $0.269^{\mathrm{NO}}$ & $0.900^{\mathrm{NO}}$ \\
\hline GM2 $\left(\mathrm{kg} \mathrm{kg}^{-1}\right)$ & $* *$ & $0.286 \pm 0.02 \mathrm{a}$ & $0.230 \pm 0.21 \mathrm{~b}$ & $0.109^{\mathrm{NO}}$ & $0.065^{\mathrm{NO}}$ \\
\hline VM2 $\left(\mathrm{m}^{3} \mathrm{~m}^{-3}\right)$ & $* *$ & $0.395 \pm 0.03 \mathrm{a}$ & $0.357 \pm 0.30 \mathrm{~b}$ & $0.085^{\mathrm{NO}}$ & $0.006^{\mathrm{IN}}$ \\
\hline $\operatorname{Vh} 2\left(\mathrm{~m}^{3} \mathrm{~m}^{-3}\right)$ & NS & $0.380 \pm 0.03$ & $0.374 \pm 0.02$ & $0.423^{\mathrm{NO}}$ & $0.001^{\mathrm{IN}}$ \\
\hline PR2 (MPa) & $* *$ & $1.018 \pm 0.37 \mathrm{~b}$ & $1.603 \pm 0.32 \mathrm{a}$ & $0.002^{\mathbb{I N}}$ & $0.092^{\mathrm{NO}}$ \\
\hline
\end{tabular}

Note. ${ }^{\mathrm{a}} \mathrm{MA}$, macroporosity; MI, microporosity; TP, total porosity; BD, bulk density; UG, gravimetric moisture; VM, volumetric moisture; Vh, volumetric moisture using Hydrosense system; PR, penetration resistance. ${ }^{b}$ Frequency distribution: NO, normal; TN, tending to normal; IN, indeterminate. Different lower-case letters in each column indicate differences between farming systems: NS not significant; ${ }^{*} \mathrm{P}<0.05 \%$ and $* * \mathrm{P}<0.01$ (with the t-student test).

Scarification was efficient in diminishing PR, which is lower than under NT (Tables 2 and 3). One of the main objectives of mechanical scarification is to decrease PR in soil (Girardello et al., 2014). Scarification helped break up compacted layers, increased MI and favored GM and VM, reducing cohesion between soil particles and PR values. Since the latter is greater in dry periods (Collares et al., 2008). Similar results were obtained by Souza et al. (2010), who also observed a drop in PR to $0.15 \mathrm{~m}$, in an Oxisol, due to soil turning under conventional tillage. The PR that limits root growth is $2 \mathrm{MPa}$ and no limitation to plant development was observed in either treatment. Higher PR values were reported by Dalchiavon et al. (2011) in Oxisol under NT. However, Almeida et al. (2008) studied Oxisol under NT and conventional tillage and found no difference for BD and GM up to $0.20 \mathrm{~m}$. These results indicate that the effect of scarification could be temporary, and that physical properties may not improve after a certain time (Nicoloso et al., 2008).

Except for HL in MT (Table 4) and GP, HL and POP in NT (Table 5), which exhibited a pure nugget effect, the remaining plant and soil properties (Tables 6 and 7) showed spatial dependence. These were fitted in the spherical and exponential model, indicating that spatial distributions were not random. Similar behavior was observed by Dalchiavon et al. (2011), who found a spherical model for LP, GP and seed weight per plant, in Oxisol planted with soybean under NT. The spherical model has been applied primarily to describe the variability of soil properties (Cambardella et al., 1994; Oliveira et al., 2013; Ribeiro et al., 2016). Cortez et al. (2017) reported greater exponential model fit for PR, in both NT and scarification. Ribeiro et al. (2016) observed spatial dependence, with spherical models for BD and moisture in Oxisol, under NT and conventional tillage. The nugget effect showed a value of zero for all the components and properties assessed. Nugget effect values close to zero indicate more accurate estimates using kriging (Cortez et al., 2018). This occurs because the lower 
the nugget effect in relation to the variogram baseline, the higher the continuity of the phenomenon and variance of the estimate, and the more reliable the estimate (Bottega et al., 2013; Cortez et al., 2018).

Table 4. Simple semivariogram parameters of the yield components and soybean yield under minimum tillage

\begin{tabular}{lllllll}
\hline Properties $^{\mathrm{a}}$ & Model $^{\mathrm{b}}$ & Nugget Effect $\left(\mathrm{C}_{0}\right)$ & Sill $\left(\mathrm{C}_{0}+\mathrm{C}\right)$ & Range $(\mathrm{m})$ & $\mathrm{r}^{2}$ & RSS $^{\mathrm{c}}$ \\
\hline GY $\left(\mathrm{kg} \mathrm{ha}^{-1}\right)$ & sph (79) & $5.750 \times 10^{4}$ & $2.467 \times 10^{5}$ & 31.3 & 0.863 & $1.430 \times 10^{9}$ \\
MOG $(\mathrm{g})$ & $\operatorname{sph}(82)$ & $4.220 \times 10^{-1}$ & 1.13 & 56.5 & 0.966 & $1.000 \times 10^{-2}$ \\
LP & sph (66) & $1.961 \times 10$ & $4.020 \times 10$ & 43.7 & 0.980 & 3.83 \\
GP & $\operatorname{exp~(67)~}$ & $2.360 \times 10$ & $1.783 \times 10^{2}$ & 24.9 & 0.709 & $7.340 \times 10^{2}$ \\
GL & $\operatorname{exp~(66)~}$ & $2.620 \times 10^{-3}$ & $1.544 \times 10^{-2}$ & 23.4 & 0.845 & $2.031 \times 10^{-6}$ \\
HP (m) & sph (67) & $8.210 \times 10^{-4}$ & $2.572 \times 10^{-3}$ & 43.9 & 0.959 & $5.558 \times 10^{-8}$ \\
HL (m) & nef. & $3.690 \times 10^{-4}$ & $3.690 \times 10^{-4}$ & - & - & - \\
POP & $\operatorname{exp~(67)~}$ & $4.010 \times 10^{7}$ & $2.880 \times 10^{8}$ & 30.3 & 0.901 & $8.970 \times 10^{14}$ \\
\hline
\end{tabular}

Note. ${ }^{\mathrm{a}} \mathrm{GY}$, grain yield of soybean; MOG, mass of one thousand grains; LP, number of legumes per plant; GP, number of grains per plant; GL, number of grains per legume; HP, plant height; HL, height of insertion of the first legume; POP, final population of soybean plants. ${ }^{b}$ Models; exp, exponential; sph, spherical; nef, pure nugget effect and in parentheses the number of pairs in the first lag. ${ }^{c} \mathrm{RSS}$, Residual sum of squares.

Table 5. Simple semivariogram parameters of the yield components and soybean yield under no-tillage

\begin{tabular}{lllllll}
\hline Properties $^{\mathrm{a}}$ & Model $^{\mathrm{b}}$ & Nugget Effect $\left(\mathrm{C}_{0}\right)$ & Sill $\left(\mathrm{C}_{0}+\mathrm{C}\right)$ & Range $(\mathrm{m})$ & $\mathrm{r}^{2}$ & RSS $^{\mathrm{c}}$ \\
\hline GY $\left(\mathrm{kg} \mathrm{ha}^{-1}\right)$ & sph $(70)$ & $8.300 \times 10^{3}$ & $1.851 \times 10^{5}$ & 21.1 & 0.815 & $7.530 \times 10^{8}$ \\
MOG $(\mathrm{g})$ & sph (64) & $3.310 \times 10^{-1}$ & $6.720 \times 10^{-1}$ & 31.1 & 0.632 & $1.750 \times 10-^{2}$ \\
LP & sph (75) & $2.190 \times 10$ & $5.596 \times 10$ & 32 & 0.839 & $6.070 \times 10$ \\
GP & sph (72) & $1.641 \times 10^{2}$ & $3.359 \times 10^{2}$ & 36.4 & 0.957 & $4.410 \times 10^{2}$ \\
GL & nef. & $2.898 \times 10^{-2}$ & $2.898 \times 10^{-2}$ & - & - & - \\
HP (m) & sph (69) & $2.210 \times 10^{-3}$ & $5.440 \times 10^{-3}$ & 94.6 & 0.929 & $7.570 \times 10^{-7}$ \\
HL (m) & nef. & $2.630 \times 10^{-4}$ & $2.630 \times 10^{-4}$ & - & - & - \\
POP & nef. & $4.187 \times 10^{8}$ & $4.187 \times 10^{8}$ & - & - & - \\
\hline
\end{tabular}

Note. ${ }^{\mathrm{a}} \mathrm{GY}$, grain yield of soybean; MOG, mass of one thousand grains; LP, number of legumes per plant; GP, number of grains per plant; GL, number of grains per legume; HP, plant height; HL, height of insertion of the first legume; POP, final population of soybean plants. ${ }^{b}$ Models; exp, exponential; sph, spherical; nef, pure nugget effect and in parentheses the number of pairs in the first lag. ${ }^{c} \mathrm{RSS}$, Residual sum of squares.

Table 6. Simple semivariogram parameters of soil properties under minimum tillage

\begin{tabular}{|c|c|c|c|c|c|c|}
\hline Properties $^{\mathrm{a}}$ & Model $^{b}$ & Nugget Effect $\left(\mathrm{C}_{0}\right)$ & Sill $\left(\mathrm{C}_{0}+\mathrm{C}\right)$ & Range $(\mathrm{m})$ & $\mathrm{r}^{2}$ & $\mathrm{RSS}^{\mathrm{c}}$ \\
\hline $\mathrm{TP} 1\left(\mathrm{~m}^{3} \mathrm{~m}^{-3}\right)$ & sph (76) & $8.150 \times 10^{-4}$ & $1.640 \times 10^{-3}$ & 77.40 & 0.814 & $1.086 \times 10^{-7}$ \\
\hline BD2 $\left(\mathrm{kg} \mathrm{dm}^{-3}\right)$ & sph (75) & $4.930 \times 10^{-3}$ & $1.046 \times 10^{-2}$ & 59.40 & 0.870 & $3.226 \times 10^{-6}$ \\
\hline PR1 (MPa) & $\exp (62)$ & $1.024 \times 10^{-2}$ & $3.308 \times 10^{-2}$ & 49.80 & 0.804 & $3.496 \times 10^{-5}$ \\
\hline PR2 (MPa) & $\exp (78)$ & $1.780 \times 10^{-2}$ & $1.1416 \times 10^{-1}$ & 35.40 & 0.878 & $3.509 \times 10^{-4}$ \\
\hline
\end{tabular}

Note. ${ }^{\mathrm{a}} \mathrm{TP}$, total porosity; BD, bulk density; PR, penetration resistance. 1 and 2 are soil layers $0.00-0.10 \mathrm{~m}$ and 0.10-0.20 m, respectively. ${ }^{\mathrm{b}}$ Models; exp, exponential; sph, spherical; nef, pure nugget effect and in parentheses the number of pairs in the first lag. ${ }^{c} \mathrm{RSS}$, Residual sum of squares.

Table 7. Simple semivariogram parameters of soil properties under no-tillage

\begin{tabular}{lllllll}
\hline Properties $^{\mathrm{a}}$ & Model $^{\mathrm{b}}$ & Nugget Effect $\left(\mathrm{C}_{0}\right)$ & Sill $\left(\mathrm{C}_{0}+\mathrm{C}\right)$ & Range $(\mathrm{m})$ & $\mathrm{r}^{2}$ & RSS $^{\mathrm{c}}$ \\
\hline TP1 $\left(\mathrm{m}^{3} \mathrm{~m}^{-3}\right)$ & $\operatorname{sph}(68)$ & $4.300 \times 10^{-4}$ & $8.610 \times 10^{-4}$ & 68.2 & 0.853 & $2.339 \times 10^{-8}$ \\
BD1 $\left(\mathrm{kg} \mathrm{dm}^{-3}\right)$ & $\exp (82)$ & $1.200 \times 10^{-3}$ & $9.700 \times 10^{-3}$ & 23.1 & 0.502 & $3.726 \times 10^{-6}$ \\
VM1 $\left(\mathrm{m} \mathrm{m}^{3}\right)$ & $\operatorname{sph}(68)$ & $4.100 \times 10^{-4}$ & $8.400 \times 10^{-4}$ & 56.2 & 0.885 & $1.411 \times 10^{-8}$ \\
Vh1 $\left(\mathrm{m}^{3} \mathrm{~m}^{-3}\right)$ & sph (72) & $7.750 \times 10^{-4}$ & $1.560 \times 10^{-3}$ & 34.4 & 0.889 & $2.246 \times 10^{-8}$ \\
\hline
\end{tabular}

Note. ${ }^{\mathrm{a}} \mathrm{TP}$, total porosity; $\mathrm{BD}$, bulk density; $\mathrm{VM}$, volumetric moisture; Vh, volumetric moisture using Hydrosense system. 1 and 2 are soil layers $0.00-0.10 \mathrm{~m}$ and 0.10-0.20 m, respectively. ${ }^{\mathrm{b}}$ Models; exp, exponential; sph, spherical; nef, pure nugget effect and in parentheses the number of pairs in the first lag. ${ }^{c}$ RSS, Residual sum of squares. 
The highest range obtained under MT were MOG, HP, LP, GY, TP1 and BD2 (Tables 4 and 6), and HP, GP, TP1, VM1 and Vh1 under NT (Tables 5 and 7), indicating that they can be used to create more accurate kriging maps since they exhibit less spatial data variability in the area. Range is the distance over which sampling points are spatially correlated (Ribeiro et al., 2016). In relation to thematic maps, the higher the range, the more accurate the kriging estimate (Alves et al., 2014). In this respect, according to Dalchiavon et al. (2011), the range values used in geostatistical packages that feed the computer packages applied in precision agriculture should consider the smallest ranges. As such, they should not be less than $23.4 \mathrm{~m}$ and $21.1 \mathrm{~m}$, respectively for MT and NT, since these are the distances within which the values of a certain property are equal.

The behavior of plant and soil properties was assessed using kriging maps (Figures 2 and 3), classified into five amplitude classes. In Figure 2 under MT, the highest GY are observed from the eastern to western part of the map. Spatially, the highest MOG and GL and lowest HP values were obtained in the eastern part of the map, indicating that these components influenced GY. Thus, MOG exhibited greater influence on GY, given that a $2 \mathrm{~g}$ variation in MOG increased GY by more than $500 \mathrm{~kg} \mathrm{ha}^{-1}$. Moreover, the region with the highest GY (eastern region) coincides with the highest TP1 and lowest BD2 values, because MT provides better decompaction conditions, prompting better plant development. Thus, from the spatial standpoint of the study area, MOG, GL, TP1 and BD2 showed the same trend and are good indicators of GY under MT.
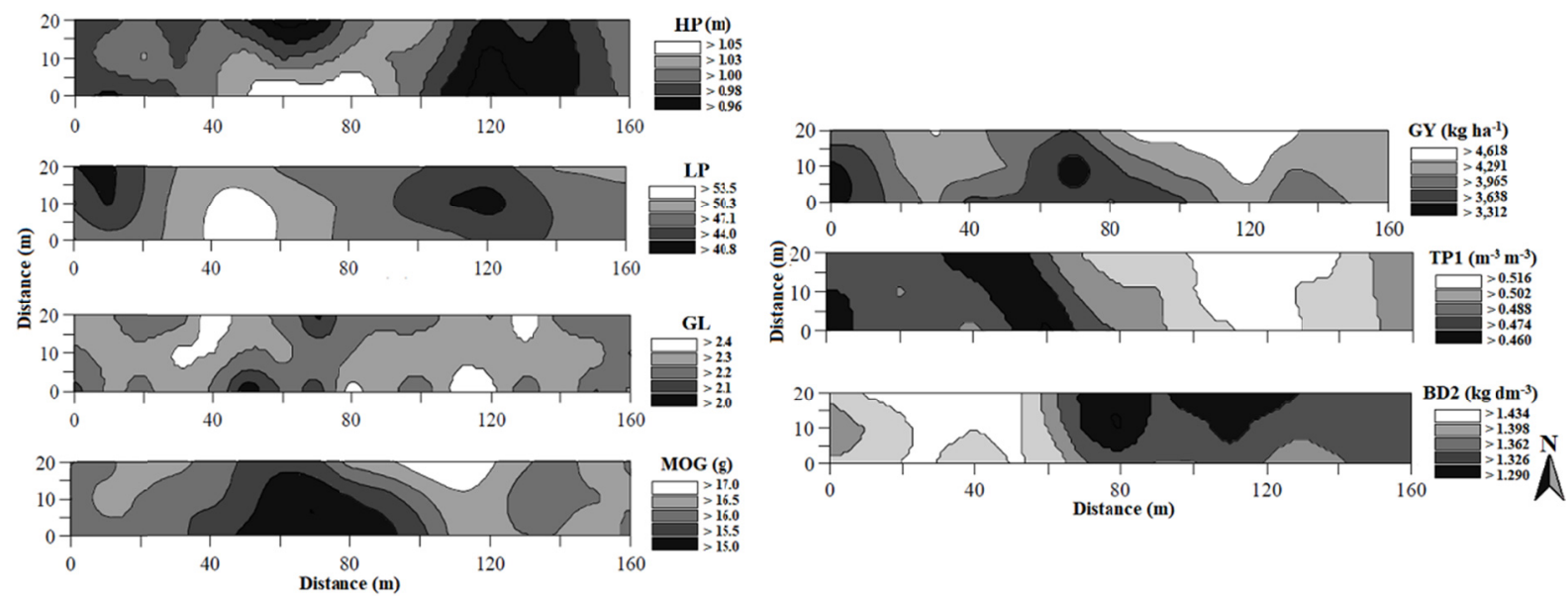

Figure 2. Kriging maps of physical properties and yield components, grain yield of soybean and soil physical properties in Oxisol under minimum tillage
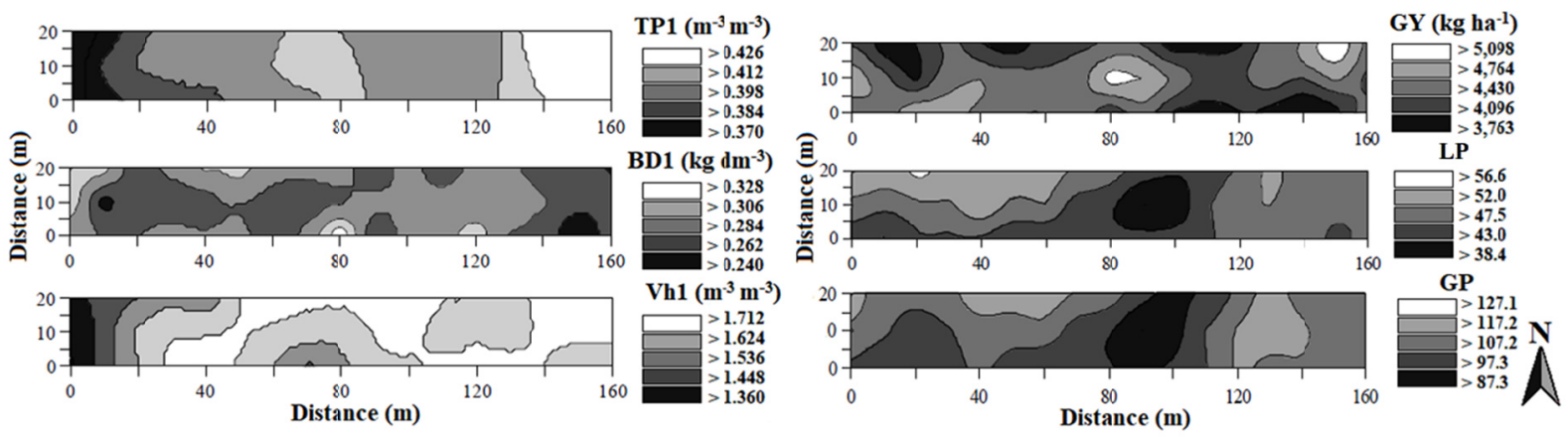

Figure 3. Kriging maps of physical properties and yield components, grain yield of soybean and soil physical properties in Oxisol under no-tillage

The higher GY in NT (Figure 3) is located in the central region moving toward the eastern region of the map, while LP and GP obtained the lowest values in these regions. This suggests that the yield components of soybean followed different patterns between the systems assessed. As such, the higher GY in NT was not a function of the yield components. Spatially, the kriging map (Figure 3) shows that TP1 was similar to GY, demonstrating the former's greater influence, given that Vhl was homogeneous in the entire area, confirming that the higher GY in the NT is a result of TP1. Thus, in the NT area, TP1, VM1 and Vh1 are possible indicators of GY, 
suggesting the importance of plant residues on the soil surface, since direct relationships were observed between soil moisture and GY, in order to create more accurate kriging maps, HP, GP and TP1 can be used under high soil soil moisture conditions.

\section{Conclusion}

The largest population of NT plants showed no spatial dependence and did not influence GY, but the components related to plant height were different between systems.

The MA, MI, TP, BD, GM, VM and PR, in the layers assessed were higher with scarification.

Spatially, the maps show that in MT, GY was influenced by MOG and GL, and greater in areas with higher TP1 and BD2 values, demonstrating that using some of these properties may produce more accurate maps.

The kriging maps illustrate the distribution of soil physical properties and their influence on soybean yield, making them an important tool for more accurate seed production planning in these areas.

\section{References}

Almeida, V. P., Alves, M. C., Silva, E. C., \& Oliveira, A. S. (2008). Crop rotation and physical and chemical properties of a red latosol in the cerrado under conventional tillage and recent no-tillage. Revista Brasileira de Ciência do Solo, 32, 1227-1237. https://doi.org/10.1590/S0100-06832008000300031

Alves, S. M. F., Queiroz, D. M., Alcântara, G. R., \& Reis, E. F. (2014). Spatial variability of physical and chemical attributes of soil using techniques of principal component analysis and geoestatisc. Bioscience Journal, 30, 22-30.

Araújo, M. A., Tormena, C. A., Inoue, T. T., \& Costa, A. C. S. (2004). Effects of chiseling on physical quality of a dystroferric red latosol after thirteen yearsof no-tillage. Revista Brasileira de Ciência do Solo, 28, 495-504. https://doi.org/10.1590/S0100-06832004000300011

Aubert, B. A., Schroeder, A., \& Grimaudo, J. (2012). It as enabler of sustainable farming: An empirical analysis of farmers' adoption decision of precision agriculture technology. Decision Support Systems, 54, 510-520. https://doi.org/10.1016/j.dss.2012.07.002

Bertolini, E. V., \& Gamero, C. A. (2010). Energy demand and corn yield with fertilizer application before sowing in two soil tillage systems. Revista Energia na Agricultura, 25, 1-23. https://doi.org/10.17224/ EnergAgric.2010v25n3p01-23

Betzek, N. M., Souza, E. G., Bazzi, C. L., Sobjak, R., Bier, V. A., \& Mercante, E. (2017). Interpolation methods for thematic maps of soybean yield and soil chemical attributes. Semina-Ciências Agrárias, 38, 1059-1069. https://doi.org/10.5433/1679-0359.2017v38n2p1059

Bottega, E. L., Queiroz, D. M., Pinto, F. A. C., Souza, C. M. A., \& Valente, D. S. M. (2017). Precision agriculture applied to soybean: Part I-Delineation of management zones. Australian Journal of Crop Science, 11, 573-579. https://doi.org/10.21475/ajcs.17.11.05.p381

Bottega, E. L., Queiroz, D. M., Pinto, F. A. C., \& Souza, C. M. A. (2013). Spatial variability of soil attributes in no a no-tillage system with crop rotation in thebrazilian savannah. Revista Ciencia Agronômica, 44, 1-9. https://doi.org/10.1590/S1806-66902013000100001

Cambardella, C. A., Moorman, T. B., Novak, J. M., Parkin, T. B., Karlen, D. L., Turco, R. F., \& Konopka, A. E. (1994). Field-scale variability of soil properties in central Iowa soils. Soil Science Society of America Journal, 58, 1501-1511. https://doi.org/10.2136/sssaj1994.03615995005800050033x

Collares, G. L., Reinert, D. J., Reichert, J. M., \& Kaiser, D. R. (2008). Traffic-induced compaction of an oxisol and its relation with growth and yield of common bean and wheat. Revista Brasileira de Ciência do Solo, 32, 933-942. https://doi.org/10.1590/S0100-06832008000300003

Cortez, J. W., Matos, W. P. S., Arcoverde, S. N. S., Cavassini, V. H., \& Valente, I. Q. M. (2018). Spatial variability of soil resistance to penetration in no-tillage system. Engenharia Agrícola, 38, 697-704. https://doi.org/10.1590/1809-4430-eng.agric.v38n5p697-704/2018

Cortez, J. W., Munir, M., Souza, L. C. F., Rufino, M. V., \& Souza, P. H. N. (2017). Agronomical attributes of soybeans and soil resistance to penetration in no-tillage and chiseled surfaces. Engenharia Agrícola, 37, 98-105. https://doi.org/10.1590/1809-4430-eng.agric.v37n1p98-105/2017 
Dalchiavon, F. C., Carvalho, M. P., Nogueira, D. C., Romano, D., Abrantes, F. L., Assis, J. T., \& Oliveira, M. S. (2011). Soybean yield and mechanical resistance to soil penetration under no-tillage in the brazilian savannah. Pesquisa Agropecuária Tropical, 41, 8-19. https://doi.org/10.5216/pat.v41i1.8351

Dam, R. F., Mehdi, B. B., Burgess, M. S. E., Madramootoo, C. A., Mehuys, G. R., \& Callum, I. R. (2005). Soil Bulk density and crop yield under eleven consecutive years of corn with different tillage and residue practices in a sandy loam soil in central Canada. Soil and Tillage Research, 84, 41-53. https://doi.org/ 10.1016/j.still.2004.08.006

Donagema, G. K., Campos, D. V. B., Calderano S. B., Teixeira, W. G., \& Viana, J. H. M. (2011). Manual de métodos de análise de solos (2nd ed., p. 230). Rio de Janeiro: Embrapa Solo.

Franchini, J. C., Costa, J. M., Debiasi, H., \& Torres, E. (2011). Importância da rotação de culturas para a produção agrícola sustentável no Paraná (p. 52). Londrina: Embrapa Soja.

Freitas, P., \& Landers, J. (2014). The Transformation of Agriculture in Brazil Through Development and Adoption of Zero Tillage Conservation Agriculture. International Soil and Water Conservation Research, 2, 35-46. https://doi.org/10.1016/S2095-6339(15)30012-5

Girardello, V. C., Amado, T. J. C., Santi, A. L., Cherubin, M. R., Kunz, J., \& Teixeira, T. D. G. (2014). Soil penetration resistance, efficiency of mechanical chisel plowing and soybean grain yield in a clayey oxisol under long-term no-till. Revista Brasileira de Ciência do Solo, 38, 1234-1244. https://doi.org/10.1590/ S0100-06832014000400020

Godoy, S. G., Stone, L. F., Ferreira, E. P. B., Cobucci, T., \& Lacerda, M. C. (2015). Correlation between upland rice yield under no-tillage system and soil attributes. Revista Brasileira de Engenharia Agrícola e Ambiental, 19, 119-125. https://doi.org/10.1590/1807-1929/agriambi.v19n2p119-125

GS+. (2004). Geostatistics for environmental sciences (7th ed.). Plainwell: Gamma Design Software.

Kassam, A., Friedrich, T., \& Derpsch, R. (2019). Global spread of conservation agriculture. International Journal of Environmental Studies, 76, 29-51. https://doi.org/10.1080/00207233.2018.1494927

Mazurana, M., Levien, R., Müller, J., \& Conte, O. (2011). Soil tillage systems: Changes in soil structure and crop response. Revista Brasileira de Ciência do Solo, 35, 1197-1206. https://doi.org/10.1590/S0100-06832 011000400013

Moraes, M. T., Debiasi, H., \& Franchini, J. (2017). Soybean and wheat response to cropping and tillage system after two decades in an oxisol under subtropical climate in Brazil. Revista Scientia Agraria, 18, 146-153. https://doi.org/10.5380/rsa.v18i3.51553

Nicoloso, R. S., Amado, T. J. C., Schneider, S., Lanzanova, M. E., Girardello, V. C., \& Bragagnolo, J. (2008). Efficiency of mechanical and biological chiseling in the improvement of physical attributes of a heavy clay oxisol and the increment of soybean yield. Revista Brasileira de Ciencia do Solo, 32, 1723-1734. https://doi.org/10.1590/S0100-06832008000400037

Nunes, M. R., Pauletto, E. A., Denardin, J. E., Faganello, A. \& Pinto, L. F. S., \& Scheunemann, T. (2014). Persistence of chiseling effects on the compaction of a Nitisol under no-till in a humid subtropical region. Pesquisa Agropecuária Brasileira, 49, 531-539. https://doi.org/10.1590/S0100-204X2014000700005

Oliveira, I. R., Teixeira, D. B., Panosso, A. R., Camargo, L. A., Marques Júnior, J., \& Pereira, G. T. (2013). Geostatistical modeling of uncertainty of thespatial distribution of available phosphorus insoil in a sugarcane field. Revista Brasileira de Ciência do Solo, 37, 1481-1491. https://doi.org/10.1590/ S0100-06832013000600005

Pereira, D. S., Montanari, R., Oliveira, C. F., Ramos, J. C. A., Panosso, A. R., Souza, Z. M. \& González, A. P. (2018b). Physical Quality of an Oxisol in Different Agricultural Systems in Brazilian Cerrado. Journal of Agricultural Science, 10, 46-54. https://doi.org/10.5539/jas.v10n7p46

Pereira, J. O., Melo, D., Richard, G., Defossez, P., Silva, S. L., Oliveira, F. A., Bastista, R. O., \& Garcia, A. R. G. (2018a). Yield of soybean crop in function of soil compaction affected by tillage system on Oxisol of subtropical region. Australian Journal of Crop Science, 12, 227-234.

Pivetta, L. A., Castoldi, G., Santos, G. C., \& Rosolem, C. A. (2011). Soybean root growth and activity as affected by the production system. Pesquisa Agropecuária Brasileira, 46, 1547-1554. https://doi.org/ $10.1590 / \mathrm{S} 0100-204 \mathrm{X} 2011001100017$ 
R Core Team. (2014). R: A language and environment for statistical computing. Vienna: R Foundation for Statistical Computing.

Raij, B. (1991). Fertilidade do solo e adubação (p. 343). Piracicaba, SP: Ceres: Potafós.

Cantarella, H., Raij, B. van, \& Camargo, C. E. O. (1997). Recomendações de calagem e adubação para o estado de São Paulo. In B. van Raij, H. Cantarella, J. A. Quaggio, \& A. M. C. Furlani (Eds.), Boletim Técnico (p. 285). Campinas: Instituto Agronômico de Campinas.

Ribeiro, L. S., Oliveira, I. R., Dantas, J. S., Silva, C. V., Silva, G. B., \& Azevedo, J. R. (2016). Spatial variability of physical attributes of a cohesive soil under conventional and no-tillage management systems. Pesquisa Agropecuária Tropical, 51, 1699-1702. https://doi.org/10.1590/S0100-204X2016000900071

Rosa Filho, G., Carvalho, M. P., Andreotti, M., Montanari, R., Binotti, F. F. S., \& Gioia, M. T. (2009). Soybean yield variabillity regarding physical properties of a typic acrustox under no-tillage. Revista Brasileira de Ciência do Solo, 33, 283-293. https://doi.org/10.1590/S0100-06832009000200006

Santos, H. G., Jacomine, P. K. T., Anjos, L. H. C., Oliveira, V. Á., Lumbreras, J. F., Coelho, M. R., ... Oliveira, J. B. (2013). Sistema brasileiro de classificação de solos (3rd ed., p. 353). Brasília: Embrapa.

SAS Institute Incorporation. (2001). The SAS-System for Windows release 8.02 (TS2M0). SAS Institute Inc., Cary, NC, USA.

Silveira, P. M., Stone, L. F., Alves Junior, J., \& Silva J. G. (2008). Effects of soil tillage and crop rotation systems on bulk density and soil porosity of a dystrophic red latosol. Bioscience Journal, 24, 53-59.

Souza, F. R., Rosa Júnior, E. J., Fietz, C. R., Bergamin, A. C., Venturoso, L. R., \& Rosa, Y. B. C. J. (2010). Physical attributes and performance of soybean in Oxisol under two management systems. Ciência e Agrotecnologia, 34, 1357-1364. https://doi.org/10.1590/S1413-70542010000600001

Stolf, R., Murakami, J. H., Brugnaro, C., Silva, L. G., Silva, L. C. F., \& Margarido, L. A. C. (2014). Stolf impact penetrometer-computer data programin excel-vba. Revista Brasileira de Ciência do Solo, 38, 774-782. https://doi.org/10.1590/S0100-06832014000300009

Tavares Filho, J., Guimarães, M. F., Curmi, P., \& Tessier, D. (2012). Physical properties of an Alfisol and no-till soybean yield. Revista Brasileira de Ciência do Solo, 36, 253-260. https://doi.org/10.1590/S0100-06832 012000100026

Teixeira, P. C., Donagemma, G. K., Fontana, A., \& Teixeira, W. G. (2017). Manual de métodos de análise de solo (3rd ed., p. 573) Brasília: Embrapa Informação Tecnológica.

\section{Copyrights}

Copyright for this article is retained by the author(s), with first publication rights granted to the journal.

This is an open-access article distributed under the terms and conditions of the Creative Commons Attribution license (http://creativecommons.org/licenses/by/4.0/). 